\title{
Tiger grass (Thysanolaena maxima) cultivation in CALSANAG watershed in Romblon, Philippines: dilemmas and prospects for sustainable natural resources management
}

\author{
LEILA D. LANDICHO ${ }^{1}$, MARIA THERESA NEMESIS P. OCAMPO ${ }^{1}$, ROWENA ESPERANZA D. CABAHUG ${ }^{1}$, \\ ROMNICK S. BALITON ${ }^{2}$, EDGAR V. ANDALECIO ${ }^{3}$, RAYMUND INOCENCIO ${ }^{4}$, MARCELINA V. SERVANEZ ${ }^{5}$, \\ RUSSEL SON A. COSICO ${ }^{1}$, ARNOLD KARL A. CASTILLO ${ }^{1}$, LYN DJ. FAMISARAN ${ }^{5}$ \\ ${ }^{1}$ Institute of Agroforestry, University of the Philippines Los Banos. College, Batong Malake, Laguna 4031, Philippines \\ ${ }^{2}$ Institute of Renewable Natural Resources, University of the Philippines Los Banos. College, Batong Malake, Laguna 4031, Philippines \\ ${ }^{3}$ Romblon State University. Odiongan, Romblon, Philippines \\ ${ }^{4}$ Provincial Environment and Natural Resources Office, Department of Environment and Natural Resources. Odiongan, Romblon, Philippines \\ ${ }^{5}$ Department of Science and Technology, MIMAROPA, Provincial Science and Technology Center. Odiongan, Romblon, Philippines
}

Manuscript received: 4 March 2020. Revision accepted: 30 April 2020.

\begin{abstract}
Landicho LD, Ocampo MTNP, Cabahug RED, Baliton RS, Andalecio EV, Inocencio R, Servanez MV, Cosico RSA, Catillo AKA,Famisaran LDJ. 2020. Tiger grass (Thysanolaena maxima) cultivation in CALSANAG watershed in Romblon, Philippines: dilemmas and prospects for sustainable natural resources management. Biodiversitas 21: 2322-2330. Promoting sustainable natural resources management is a complex issue such that striking a balance between socioeconomic productivity and environmental integrity remains a challenge. This paper highlights the results of a study conducted from April to December 2019, which assessed the state of natural resources management in Barangay Mari-norte, San Andres, Romblon, which is part of the CALSANAG (Calatrava, San Andres, and San Agustin) Watershed. Biophysical characterization was done to determine land use and biodiversity, while farm household survey was administered to 133 farmers to characterize their socioeconomic conditions. Results showed that all of the farmerrespondents were engaged in the production of tiger grass (Thysanolaena maxima Roxb), where most of the farm households derived an estimated annual income of >Php50,000. Although their household income is higher as compared to other upland farming communities in the Philippines, most of them expressed that their income is insufficient since tiger grass is harvested only once a year, and the farmers have no alternative sources of income. On the other hand, biophysical characterization revealed the following: the farms are generally rainfed, have rolled to steep slopes, and have indications of low soil fertility, soil erosion incidence, and very low level of biodiversity (0.92). Most of the farmers practiced "slash-and-burn" to cultivate tiger grass as a single crop and hence, the forest cover has declined. A multi-agency collaboration jointly initiated agroforestry promotion in the upland farming communities through capability-building of upland farmers in agroforestry and establishment of tiger grass-based agroforestry model which showcases the economic and ecological viability of agroforestry systems in CALSANAG Watershed.
\end{abstract}

Keywords: Agroforestry model, biodiversity, upland farming communities, income, slash-and-burn

\section{INTRODUCTION}

Sustainable natural resources management is a perennial concern in many developing countries. In the Philippines, striking a balance between environmental development and economic growth remains a challenge. Antonio et al. (2012) cited the claim of the forestry sector (Department of Environment and Natural Resources), "that the country suffers from severe deforestation as over 100,000 hectares of forest are lost every year. Forest diversity has been reduced and only 800,000 hectares of virgin forest is left ".

Because of the complex and intertwined issues on rural poverty, sustainable development and conservation, many research and conservation and development organizations have made efforts to bring non-timber forest products (NTFPs) at the center of discourse (Belcher et al. 2005; Benjade and Paudel 2008). The forest-dependent communities explore ways for their livelihoods and survival. In most cases, forest resources (i.e. lands, flora, and fauna) serve as their capitals for economic activities. In their study, Chechina et al. (2018) forwarded that incorporating local livelihoods into forest conservation strategies had a positive impact on the socio-economic conditions of the forest-dependent communities in the Philippines.

Tiger grass (Thysanolaena maxima Roxb.), which is also widely known as "broom grass" is one of the NTFPs which belong to the Poaceae family. According to Tiwari et al. (2012), tiger grass is an important NTFP which grows in almost all parts of South and Southeast Asia up to an elevation of 1600 meters and in tropical to subtropical climatic conditions.

Many upland communities in the Philippines are engaged in the production of tiger grass ( (Thysanolaena maxima (Roxb.) as a source of household income, particularly in Nueva Ecija (Armas and Moralde 2019); Benguet (Baldino 2002), Romblon (Feltavera 2011). Alam 
et al. (2013) also stressed that tiger grass is an important non-timber forest product which is collected by the tribal people in Bangladesh. Fadriquel (2016) estimated around 400 hectares of land in Tablas Island in Romblon, Philippines are planted to tiger grass primarily because of its economic potentials as a raw material for soft broom. The families are engaged in tiger grass production, trading the grass, processing the grass into soft brooms, and trading of the brooms. Value addition takes form along the value chain in the industry and benefits several other community members indirectly. The families engaged in production of the grass number about 300 and are scattered in the highlands of Calatrava, San Andres, and San Agustin, which lie within the Calatrava-San Andres-San Agustin (CALSANAG) watershed which is a protected area and proclaimed as an Important Bird Habitat. As the farmers have little knowledge of cultural practices of tiger grass they resort to slash and burn farming to avail of inherent soil fertility in the forest floors. There are claims worldwide, however, that slash-and-burn cultivation poses threats on environmental integrity, particularly deforestation (Neto et al. 2019), soil disturbances such as fine particle losses and nutrient leaching, soil fertility and agricultural sustainability (Beliveau et al. 2015).

This paper highlights the socioeconomic and environmental conditions of the selected upland farms in Barangay Mari-norte, San Andres, Romblon, Philippines with emphasis on the dilemmas and prospects of its cultivation in promoting sustainable natural resources management within the watershed.

\section{MATERIALS AND METHODS}

\section{Study site}

The study was conducted in Barangay Mari-norte, San Andres, Romblon, one of the villages within the CALSANAG Watershed (Figure 1), from March to December 2019. A farm household survey was administered to a sample of 133 farmers using pre-tested questionnaire. The respondents were selected using random sampling. The sampling size was computed following the formula below:

$$
\begin{aligned}
& \mathrm{n}=\mathrm{N} / 1+\left(\mathrm{N}^{*} \mathrm{e}^{2}\right) \\
& \text { Where: } \\
& \mathrm{n}: \text { sampling size } \\
& \mathrm{N} \text { : population of farmers in the area } \\
& \mathrm{e}: \text { sampling error }(0.05)
\end{aligned}
$$

The socioeconomic characteristics were determined using a set of pre-tested questionnaire. Key informant interviews (KII) and focus group discussions (FGD) were also conducted to validate the information and identify key issues in tiger grass production and the overall ecological/environmental status of the study site.

Results of the household survey were analyzed using descriptive statistics such as frequency counts, percentages, and weighted scores. FGD and KII results were captured using thematic analysis. Farm visit was conducted to validate the farming systems and farm components, observe occurrence and indications of soil erosion, and measure the slope of the farms.
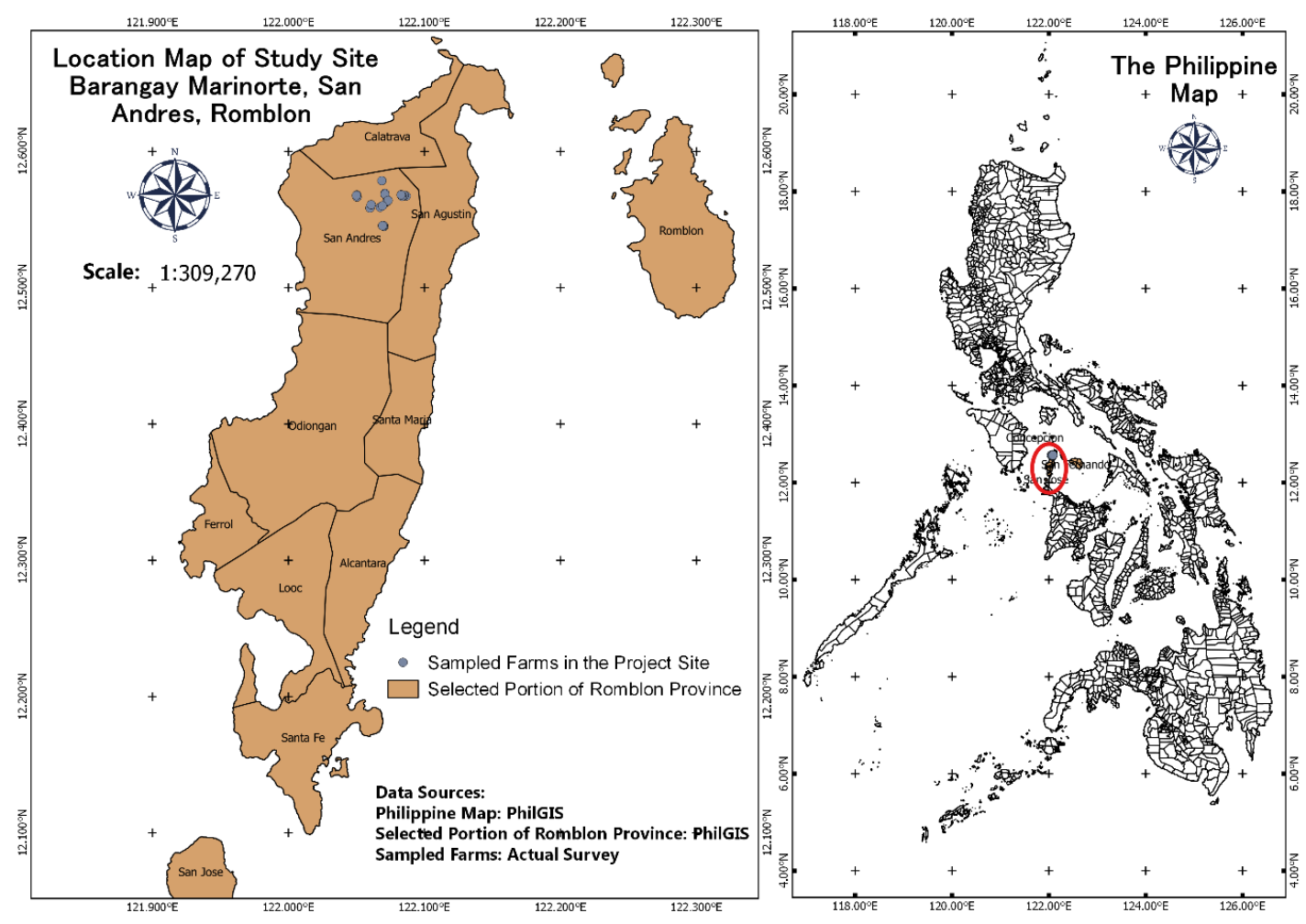

Figure 1. Location map of the study site: Barangay Mari-norte, San Andres, Romblon, Philippines 


\section{Soil sampling was conducted to facilitate soil fertility analysis}

Biodiversity assessment was conducted by measuring the parameters such as population density or the number of individual species per unit area; frequency of species distribution; relative and importance values based on density and frequency; and, diversity and evenness indices based on the relative and importance values. Importance Value (IV) was computed to determine the dominant species for each site. The IV is the sum of the relative frequency and relative coverage. These values were computed using the following formula:

Density $=\frac{\text { Total number of tree individuals counted per species }}{\text { Total Area Sampled }}$

Relative density $=\frac{\begin{array}{c}\text { Total number of tree individuals counted } \\ \text { per species } \mathrm{x} 100\end{array}}{\text { Total number of species }}$

Species frequency $=\frac{\text { Number of plots species occur } \mathrm{x} 100}{\text { Total number of plots }}$

Relative frequency $=\frac{\text { Frequency of species } \mathrm{x} 100}{\text { Total frequency of all species }}$

Importance value $=$ Relative density + Relative coverage + Relative frequency

The measures of biodiversity were obtained using the Shannon-Wiener Diversity Index $(\mathrm{H})$ with the formula used by Magurran (2004) as follows:

$$
\mathrm{H}^{\prime}=\sum_{\mathrm{i}=1}^{\mathrm{S}}-\left(\mathrm{P}_{\mathrm{i}} * \ln \mathrm{P}_{\mathrm{i}}\right)
$$

Where:

H' : Shannon-Weiner Diversity Index

$P_{i}$ : fraction of the entire population made up of species $i$

$\mathrm{S}:$ numbers of species encountered/species richness

$\sum$ : sum from species 1 to species $\mathrm{S}$

Note: The power to which the base e (e = $2.718281828 \ldots . . .$. .) must be raised to obtain a number is called the natural logarithm $(\mathrm{ln})$ of the number.

In addition, Pielou's evenness index (J) serves as a measure of the relative abundance of the different species that make up the plant community, using the following equation:

$$
\mathrm{J}=\mathrm{H}^{\prime} / \ln (\mathrm{S})
$$

Where:

J : Pielou's Evenness Index

H': Shannon's diversity index

$\ln (S)$ : natural logarithm of species richness

\section{RESULTS AND DISCUSSION}

\section{Socioeconomic and biophysical profile of the study site}

Table 1 shows that most $(63 \%)$ of the farmerrespondents were male, with a mean age of 47 years old. Most of them were married with a mean household size of five (5). More than half $(59 \%)$ of them derived their income solely from farming, and many (40\%) combined farming with non-farm activities to augment their household income. Compared with other upland farming communities with incomes ranging from PHp10000-20000 (Landicho et al. 2015; Landicho 2016), the farmers in Barangay Mari-norte had generally higher household income. About $40 \%$ had an estimated annual household income of $\mathrm{Php}>50000 ; 17 \%$ with income ranging from Php41000-50000; 12\% with income ranging from Php31000-40000; 15\% with income ranging from Php21000-30000; $15 \%$ with income ranging fromPhp10000-20000. The farmer-respondents were all engaged in tiger grass or luway production, which serves as their primary source of income. As shown in Table 1, the total farm size of the 133 farmer-respondents accounts for 348.10 hectares with a mean farm size of 2.78 hectares. As compared to the mean farm size of smallholder upland farmers of 1.50 hectares (Tolentino et al. 2010; Visco et al. 2013; Landicho et al. 2015; Landicho et al. 2017), the farm size being cultivated by the farmers in Barangay Mari-norte is relatively bigger. Of the total farm size, about 102 hectares or a mean of 0.90 hectares is allocated to tiger grass production. Many (43\%) of the farmers cultivate the farms as tenants, while a number of them (37\%) have reported owned the farms.

Table 2 shows the general biophysical characteristics of the farms in the study site, Data shows that majority of the farms are located in rolling to steep areas (combined percentage of $81 \%$ ). Most of the farmers obtain water from spring and rivers $(73 \%)$ while others rely mainly on rain for their crops. Soil in the demo farm is slightly acidic as shown by lower $\mathrm{pH}$ (5.37). Based on the soil fertility classification scheme proposed by Badayos et al (2007), soil in the demo farm has low to very low amounts of macro-nutrients.

\section{Typology of farming systems}

There are eight types of farming systems that were observed in the study site (Figure 2). These include (i) tiger grass monocropping; (ii) tiger grass + annual crops; (iii) tiger grass + perennial (fruit trees and/or coconut); (iv) tiger grass + forest species; (v) tiger grass + perennial + annual; (vi) tiger grass + perennial + forest species; (vii) tiger grass + annual + forest species; and (viii) tiger grass + perennial + annual + forest species. The perennials refer to either fruit trees or coconut, while forest species refer to forest trees and non-timber forest products particularly the vines. Annual crops refer to vegetables and root crops. Tiger grass is a prominent dominant crop across the different types of farming systems. The average farm size of upland farms in the study site is 2.78 hectares, which is higher than the mean average farm size of 1.50 hectares in 
the Philippines. An average of one-hectare is allocated for tiger grass cultivation. This indicates farmers' preference for this species, primarily because of its economic contributions to the farm household. According to Sespene et al (2011), the tiger grass industry is a promising economic activity in Marigondon Norte, San Andres, Romblon.

\section{Biodiversity assessment}

A total of 22 species were found across the 20 sampling plots, representing the top five farming systems in Barangay Mari-norte. These include tiger grass monocrop, , tiger grass + perennials, tiger grass + annuals + perennials, tiger grass + perennials + forest species, and tiger grass + annuals + perennials + forest species. These species consisted of 1801 individuals, with tiger grass (luway) being the dominant species across the sampling plots. Using the Shannon-Wiener diversity index $(\mathrm{H})$, the computed biodiversity index, and following the classification scheme proposed by Fernando et al (1998) in Table 4, results show that the diversity across the five farming systems is very low, with an index ranging from $0.00-1.28$. From the five farming systems, the combination of tiger grass + annual crops + perennials + forest species had the highest index of 1.28, while the tiger grass monocropping had the lowest (0.00). Similarly, Pielou's evenness index across the farming systems is low with a range of $0.00-0.21$, suggesting that the number of individuals per species is not evenly distributed.

\section{Challenges confronting the sustainable natural resources management in Barangay Mari-norte} Economic benefits derived from tiger grass production is not enough to meet the basic needs of the upland farmers

Growing tiger grass is a viable livelihood because of its potential in generating cash income from the harvested panicles which are processed into soft brooms (www.pcaarrd.dost.gov.ph; Faltavera, undated). As shown in Table 1, nearly half $(40 \%)$ of the farm households cultivating tiger grass derived a relatively higher annual income of more than Php50000 as compared to the other upland farming communities in the Philippines. In spite of this, however, $54 \%$ of the upland farmers reported that their income is not enough to sustain the basic needs of the households, primarily because harvesting of tiger grass is seasonal-only once a year, and the lack of alternative sources of income (Table 5). Most (84\%) of the farmers were not engaged in the processing of tiger grass into broom because of the lack of knowledge and skills in processing; lack of capital to invest on the machinery and equipment for processing; and, the assured and immediate cash when sold as raw materials.

\section{Tiger grass production poses threats to the ecological/environmental condition of the watershed}

The farmers in the study site practiced swidden cultivation, where new areas are being opened three to four years after the initial establishment of tiger grass or when the tiger grass becomes less productive. Bruun et al. (2009) highlighted that swidden cultivation puts emphasis on the rotation of fields or lands, and through fallow, sustains the production of food crops. Moreover, the farmers practice "slash-and-burn" where woody perennials or trees are cut to give way for the production of tiger grass (Figure 3). Pollini (2014) noted that slash-and-burn agriculture is a widely adopted strategy to practice agriculture in forested landscapes. While shifting cultivation and slash-and-burn system are age-old practice in the upland areas of the Philippines, conservation policies that have evolved since the 1970s restrict such practices because of the negative impacts on the environment. Hauser and Norgrove (2013) argued that partial or complete removal of vegetation has differential effects on the microclimatic and hydrological conditions after clearing such as the redistribution of rains in the absence of tall vegetation, and soil erosion in the absence of vegetation. This literature is validated by the farmers' own observations on the rampant soil erosion in farms with steep slopes. The farmers have also observed the scarcity of water in the river system especially during the dry season, which they attribute to the cutting of trees within the watershed. Results of soil analysis also indicate that the farm soils in the study site are already acidic, having a mean soil $\mathrm{pH}$ of 5.37 as shown in Table 2. Results of biodiversity assessment indicate a very low biodiversity index of 0.00-1.28. In a related study, Lucidos et al (2017) pointed out a moderate bird diversity in the Balago SubWatershed within the CALSANAG Watershed. However, the decreasing population of endemic and endangered bird species are indicators that the area is under threat due to illegal wildlife hunting, timber poaching, and land conversion.

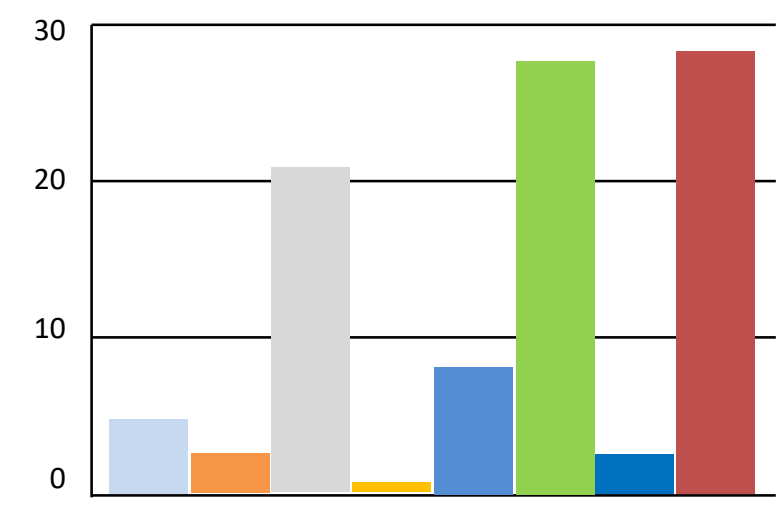

a Tiger grass monocropping

u Tiger grass + annual

a Tiger grass + perennial

a Tiger grass + forest species

a Tiger grass + perennial + annual

a Tiger grass + perennial + forest species

a Tiger grass + annual + forest species

a Tiger grass + perennial + annual + forest species

Figure 2. Typology of farming systems in the study site 
Table 1. Socioeconomic characteristics of farmer-respondents in Barangay Mari-norte, San Andres, Romblon, Philippines, 2019

\begin{tabular}{|c|c|c|}
\hline Socioeconomic characteristics & Freq. & $\%$ \\
\hline \multicolumn{3}{|l|}{ Sex } \\
\hline Male & 84 & 63 \\
\hline Female & 49 & 37 \\
\hline Mean age & 47 & \\
\hline Mean household size & 5 & \\
\hline \multicolumn{3}{|l|}{ Income sources } \\
\hline Farming & 78 & 59 \\
\hline Non-farm activities & 1 & 1 \\
\hline Farming + non-farm activities & 53 & 40 \\
\hline \multicolumn{3}{|c|}{ Estimated annual household income (in Php) } \\
\hline $10000-20000$ & & 15 \\
\hline $21000-30000$ & & 15 \\
\hline $31000-40000$ & & 12 \\
\hline $41000-50000$ & & 17 \\
\hline$>50000$ & & 40 \\
\hline Total farm size & \multicolumn{2}{|c|}{348.10 hectares } \\
\hline Mean farm size & \multicolumn{2}{|c|}{2.78 hectares } \\
\hline Total farm size with tiger grass & \multicolumn{2}{|c|}{102.2 hectares } \\
\hline Mean farm size with tiger grass & \multicolumn{2}{|c|}{0.90 hectares } \\
\hline \multicolumn{3}{|l|}{ Status of farm ownership } \\
\hline Tenant & 57 & 43 \\
\hline Farm owner & 49 & 37 \\
\hline Rents the farm & 7 & 5 \\
\hline Farm is public land & 4 & 3 \\
\hline Others & 16 & 12 \\
\hline
\end{tabular}

Table 2. Biophysical characteristics of the farms in Barangay Mari-norte, San Andres, Romblon, Philippines, 2019

\begin{tabular}{|c|c|c|c|c|c|}
\hline $\begin{array}{l}\text { Biophysical } \\
\text { characteristics }\end{array}$ & \multicolumn{3}{|c|}{ Frequency } & & $\%$ \\
\hline \multicolumn{6}{|l|}{ Topography } \\
\hline Flat & \multicolumn{3}{|c|}{25} & \multicolumn{2}{|r|}{19} \\
\hline Rolling & \multicolumn{3}{|c|}{56} & \multicolumn{2}{|r|}{42} \\
\hline Steep & \multicolumn{3}{|c|}{52} & \multicolumn{2}{|r|}{39} \\
\hline \multicolumn{6}{|l|}{ Source of water for crops } \\
\hline River & \multicolumn{3}{|c|}{53} & \multicolumn{2}{|r|}{40} \\
\hline Spring & \multicolumn{3}{|c|}{44} & \multicolumn{2}{|r|}{33} \\
\hline Rainfall & \multicolumn{3}{|c|}{36} & \multicolumn{2}{|r|}{27} \\
\hline Soil properties & 1 & 2 & 3 & 4 & Mean \\
\hline Soil pH & 5.6 & 5.4 & 5.3 & 5.2 & 5.37 \\
\hline Organic Matter (\%) & 3.19 & 2.51 & 2.94 & 2.30 & 2.71 \\
\hline Nitrogen $(\%)$ & 0.12 & 0.09 & 0.10 & 0.09 & 0.10 \\
\hline Phosphorous (ppm Bray) & 2.90 & 2.70 & 3.50 & 2.20 & 2.82 \\
\hline $\mathrm{K}\left(\mathrm{cmol}_{\mathrm{c}} / \mathrm{kg}\right.$ soil $)$ & 0.45 & 0.29 & 0.30 & 0.36 & 0.35 \\
\hline
\end{tabular}

Table 4. Classification scheme of Shannon diversity index (Fernando et al. 1998).

\begin{tabular}{ll}
\hline Relative values & Shannon-Weiner diversity index $\left(\mathbf{H}^{\prime}\right)$ \\
\hline Very High & 3.50 and above \\
High & $3.00-3.49$ \\
Moderate & $2.50-2.99$ \\
Low & $2.0-2.49$ \\
Very Low & 1.99 and below \\
\hline
\end{tabular}

Table 3. List of species, biodiversity and evenness index across the different farming systems in the study site

\begin{tabular}{|c|c|c|c|c|}
\hline Species & Scientific name & $\begin{array}{c}\text { No. } \\
\text { of } \\
\text { ind. }\end{array}$ & $\mathbf{H}$ & $\mathbf{J}$ \\
\hline \multicolumn{5}{|c|}{ Tiger grass monocropping } \\
\hline Tiger grass & Thysanolaena maxima & 122 & 0.0000 & 0.0000 \\
\hline Total & & 122 & 0.00 & 0.00 \\
\hline \multicolumn{5}{|c|}{ Tiger grass + annual } \\
\hline Tiger grass & Thysanolaena maxima & 76 & 0.3331 & 0.0673 \\
\hline Cassava & Manihot esculenta & 65 & 0.3570 & 0.0721 \\
\hline Total & & 141 & 0.69 & 0.14 \\
\hline
\end{tabular}

Tiger grass + perennial

$\begin{array}{lllll}\text { Tiger grass } & \text { Thysanolaena maxima } & 638 & 0.0904 & 0.0138\end{array}$

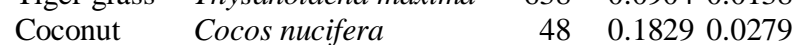

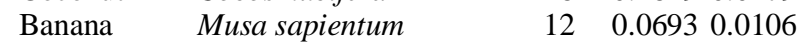

$\begin{array}{lllll}\text { Rambutan } & \text { Nephelium lappaceum } & 3 & 0.0232 & 0.0035\end{array}$

$\begin{array}{llll}\text { Jackfruit Artocarpus heterophyllus } 4 & 0.0293 & 0.0045\end{array}$

$\begin{array}{llll}\text { Total } & 705 & 0.40 & 0.06\end{array}$

Tiger grass + perennial + annual

$\begin{array}{llrrr}\text { Tiger grass } & \text { Thysanolaena maxima } & 218 & 0.2369 & 0.0415 \\ \text { Coconut } & \text { Cocos nucifera } & 11 & 0.1204 & 0.0211 \\ \text { Banana } & \text { Musa sapientum } & 13 & 0.1351 & 0.0236 \\ \text { Mango } & \text { Mangifera indica } & 2 & 0.0331 & 0.0058 \\ \text { Cassava } & \text { Manihot esculenta } & 23 & 0.1957 & 0.0343 \\ \text { Gabi } & \text { Colocasia esculenta } & 36 & 0.2531 & 0.0443 \\ \text { Total } & & 303 & 0.97 & 0.17\end{array}$

Tiger grass + perennial + forest species

$\begin{array}{lllll}\text { Tiger grass } & \text { Thysanolaena maxima } & 87 & 0.1212 & 0.0263\end{array}$

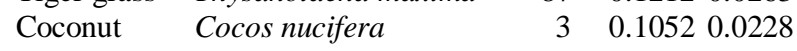

$\begin{array}{lllll}\text { Banana } & \text { Musa sapientum } & 4 & 0.1288 & 0.0280\end{array}$

$\begin{array}{lllll}\text { Calamansi } & \text { Citrofortunella microcarpa } & 1 & 0.0461 & 0.0100\end{array}$

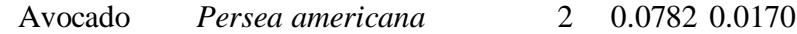

$\begin{array}{lllll}\text { Narra } & \text { Pterocarpus indicus } & 3 & 0.1052 & 0.0228\end{array}$

$\begin{array}{llll}\text { Total } & 100 & 0.58 & 0.13\end{array}$

Tiger grass + perennial + annual + forest species

Tiger grass $\quad$ Thysanolaena maxima $236 \quad 0.32930 .0543$

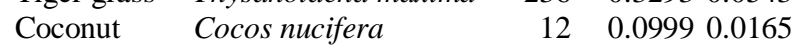

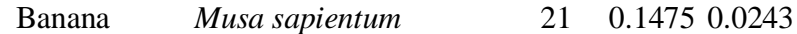

$\begin{array}{llrlll}\text { Mango } & \text { Mangifera indica } & 2 & 0.0250 & 0.0041\end{array}$

$\begin{array}{lllllll}\text { Jackfruit } & \text { Artocarpus heterophyllus } & 1 & 0.0141 & 0.0023\end{array}$

$\begin{array}{lllll}\text { Rambutan } & \text { Nephelium lappaceum } & 2 & 0.0250 & 0.0041\end{array}$

$\begin{array}{lllll}\text { Tiesa } & \text { Pouteria lucuma } & 1 & 0.0141 & 0.0023\end{array}$

$\begin{array}{lllllll}\text { Kamansi } & \text { Artocarpus camansi } & & 0.0141 & 0.0023\end{array}$

$\begin{array}{lllll}\text { Papaya } & \text { Carica papaya } & 1 & 0.0141 & 0.0023\end{array}$

$\begin{array}{lllll}\text { Cassava } & \text { Manihot esculenta } & 134 & 0.3633 & 0.0599\end{array}$

$\begin{array}{lllll}\text { Gabi } & \text { Colocasia esculenta } & 2 & 0.0250 & 0.0041\end{array}$

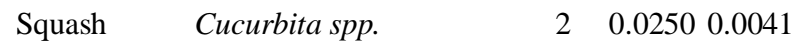

$\begin{array}{llll}\text { Eggplant } & \text { Solanum melongena } & 4 & 0.04350 .0072\end{array}$

$\begin{array}{llll}\text { Bunlaw Justicia gendarussa } & 2 & 0.0250 & 0.0041\end{array}$

Ipil-ipil Leucaena leucocephala 40.04350 .0072

$\begin{array}{lllll}\text { Kakawate } & \text { Gliricidia sepium } & 1 & 0.0141 & 0.0023\end{array}$

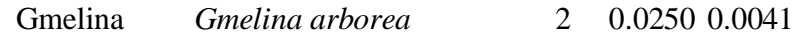

$\begin{array}{lllll}\text { Narig } & \text { Vatica mangachapoi } & 1 & 0.0141 & 0.0023\end{array}$

$\begin{array}{lllll}\text { Katilog } & \text { Ficus nota } & 1 & 0.0141 & 0.0023\end{array}$

$\begin{array}{llll}\text { Total } & 430 & 1.28 & 0.21\end{array}$

Note: H: Diversity index, J: Evenness index 
Table 5. Economic benefits of cultivating tiger grass in Barangay Mari-norte, San Andres, Romblon, Philippines

\begin{tabular}{lc}
\hline Economic information & $\begin{array}{c}\text { Percentage (\%) } \\
\text { of responses }\end{array}$ \\
\hline Annual household income & 15 \\
$10000-20000$ & 15 \\
$21000-30000$ & 12 \\
$31000-40000$ & 17 \\
$41000-50000$ & 40 \\
$>50000$ & 46 \\
Sufficiency of income to meet household's basic needs & 54 \\
Sufficient & \\
Insufficient & - \\
Reasons for the insufficiency of income & - \\
Tiger grass is harvested only once a year & - \\
School of expenses of children & 16 \\
No alternative sources of income & 84 \\
Engagement in the processing of tiger grass & \\
Process tiger grass into soft brooms & \\
Not engaged in tiger grass processing &
\end{tabular}

\section{Dominance of tiger grass in the farming system limits biodiversity and food security}

The upland farms in the study site were dominated by tiger grass, on the perception that integration of other crops within the farm parcels, particularly trees, would cause shading, which could, later on, affect the production and yield of tiger grass. While Figure 4 shows that the dominant farming system is the combination of tiger grass+annuals+perennials+forest tree species, the annuals and perennials were just planted in patches. As shown in Table 4, the number of individuals per species of perennials, annual, and forests were very few as compared to tiger grass. This practice limits the production of food and cash crops. As shown earlier, the biodiversity index in the study site is very low. This could be because of the practice of "slash-and-burn" and the farmers' preference on tiger grass. Besides limiting the biodiversity, the dominance of tiger grass also limits the potentials of the farm to contribute to the households' food security. The

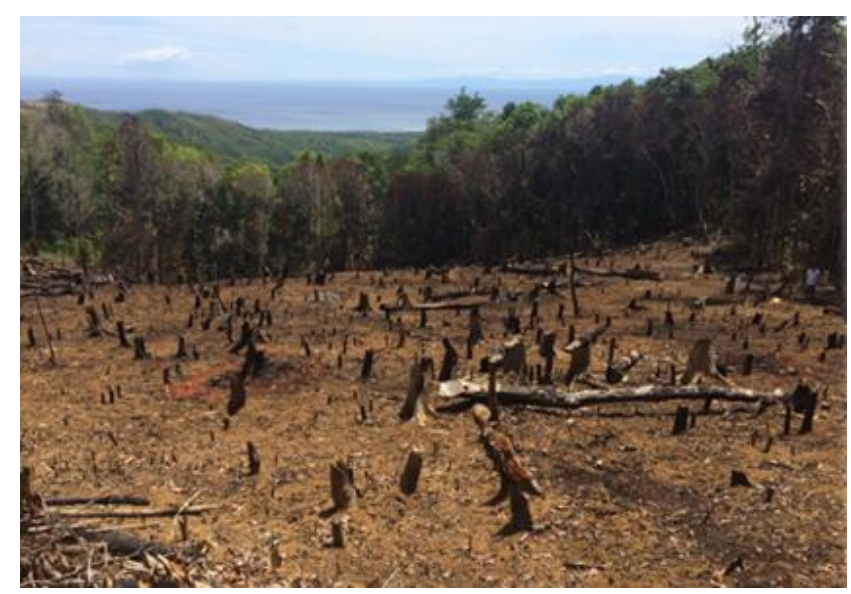

Figure 3. Slash-and-burn system is being practiced to open lands for tiger grass cultivation of food crops is a secondary priority among the upland farmers, farmers do not cultivate food crops which should have been the source of their food and nutrition.

\section{Opportunities towards sustainable natural resources management in CALSANAG watershed}

Research results revealed that farmers are already aware that their current farming system tends to contribute to ecological problems and issues. Specifically, they recognized that the practice of "slash-and-burn" and cutting of trees are destructive to the ecological conditions of the watershed. Thus, they believed that there is a need to minimize the practice of "slash-and-burn"; concentrate tiger grass farming in one production area only and minimize transfer and opening of new sites; need to plant trees to replace the tree that they have cut, and cutting of trees should be stopped. Almost all (94\%) of the tiger grass farmers perceived the need of improving their current farming practices, and are open to crop diversification, particularly integrating fruit trees in their farms.

The biophysical and socio-economic conditions of the upland farmers in the study site necessitate the promotion of tiger grass-based agroforestry system. Agroforestry is a dynamic, ecologically-based natural resource management system that through the integration of trees in farm and rangeland, diversifies and sustains smallholder production for increased social, economic and environmental benefits (Leakey 2017). According to Lasco and Visco (2003), agroforestry is characterized by two or more species of plants (or plants and animals) with at least one woody perennial; two or more outputs; usually have longer than one-year cycle; and, with significant interactions between woody and non-woody components. These characteristics of Agroforestry make it an appropriate technology intervention in the upland farming communities with marginal socioeconomic and environmental conditions. Ros-Tonen and Wiersum (2005) also highlight that contribution of non-timber forest products (NTFPs) to improve livelihoods can best be assured through a process of gradual domestication of NTFPs in agroforestry system.

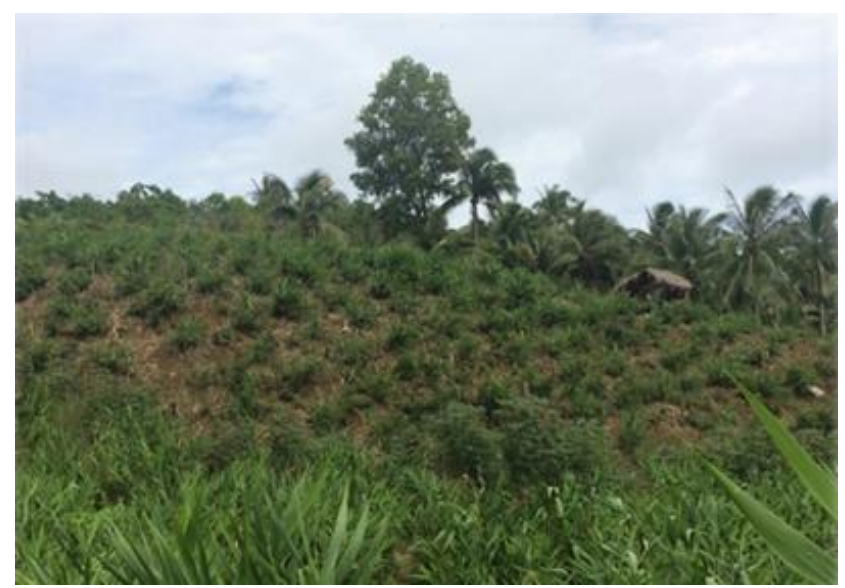

Figure 4. Tiger grass as the dominant species of the different farming systems in the study site 


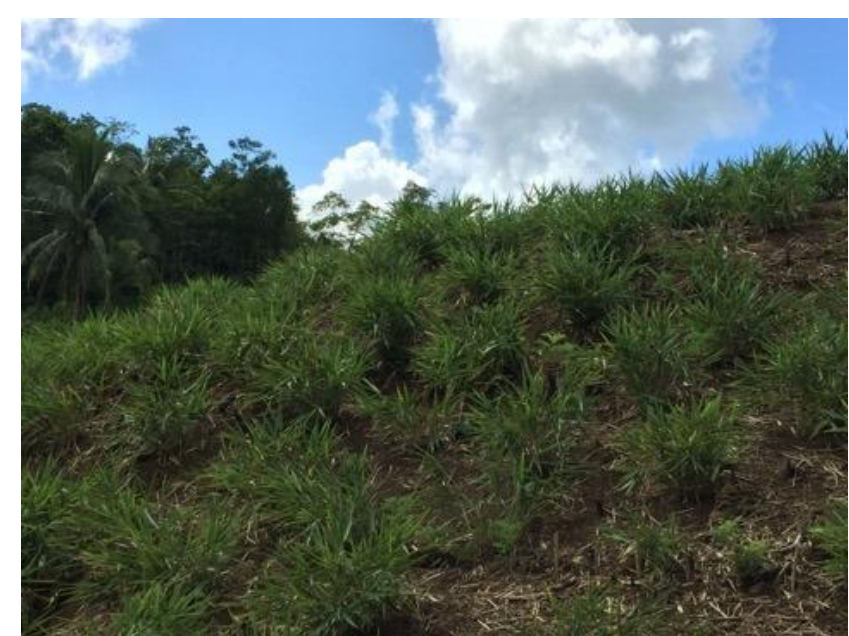

Figure 5. Tiger-based agroforestry system established in the study site

The viability of tiger grass-based agroforestry system was showcased in the study site through the establishment of a demonstration farm. Afzal (1995) in Khan et al. (2009) argued that among the major weapons to introduce the findings of modern agricultural research is through the use of extension methods such as establishment of demonstration plots. In their study, Khan et al. (2009) found out that demonstration plots were not only successful or effective means of creating awareness among the farmers about modern technologies, but also provide motivation for them to apply these technologies in their own farming practices.

The tiger grass-based agroforestry model showcases the viability of integrating short-term agricultural crops and woody perennials in the tiger grass farms to enhance socioeconomic productivity and ecological stability (Figure 5). Specifically, the agroforestry model incorporated pigeon pea (Cajanus cajan), calamansi (Citrofotunella microcarpa), and yam (Dioscorea sp.) as source of food and additional household income. In addition, pigeon pea was intercropped with tiger grass, not only as a food crop but to help restore soil fertility by fixing atmospheric nitrogen. Besides being a nutritious grain legume, Khoury et al. (2015) mentioned that pigeon pea is a stress-tolerant legume that enhances the sustainability of dry sub-tropical and tropical agricultural systems. In terms of enhancing soil condition, Sarkar et al. (2017) reported that the leaves and immature stem of pigeon pea can be used as green manure, while the fallen leaves can be used as mulch to enhance the water holding capacity of the soil. Based on first two (2) years data, the prediction analysis by Bora (2014) projects a profit of Rs 6.6 lakh/ha and Rs 8.1 lakh/ha under broom grass monoculture and when intercropped with pigeon pea respectively within a period of four (4) years. Pili (Canarium ovatum) was integrated along the farm boundaries to serve as windbreak and provide as an additional income source in the long run. Pili is suitable for windbreak in agroforestry systems, having a remarkable resistance to strong winds (Coronel 1996), and

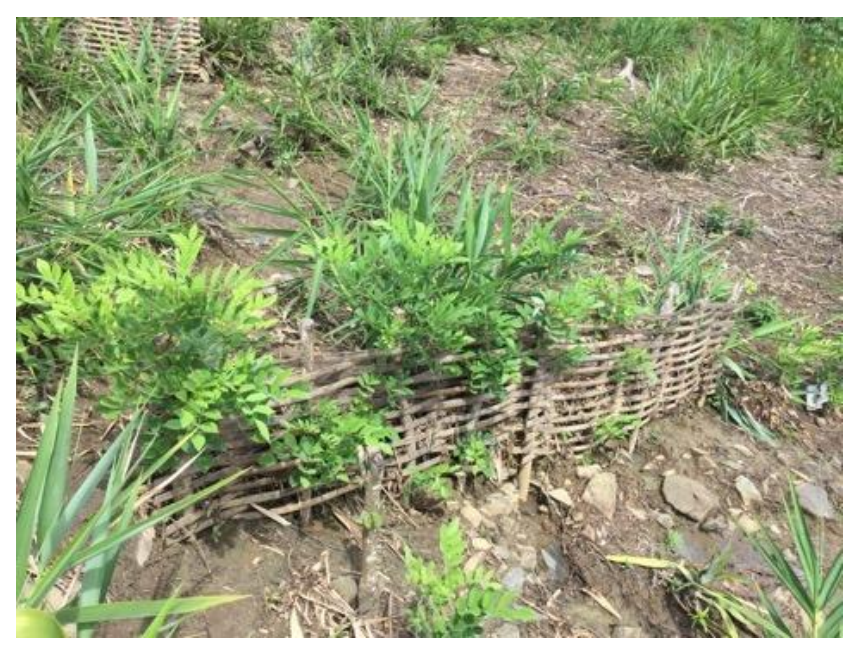

Figure 6. Check dam as one of the soil and water conservation measures

hence, making it a good living windbreak for other crops. Tiger grass was retained as the dominant species in the agroforestry model being the primary source of household income. Soil and water conservation measures were showcased through the establishment of hedgerows and check dams (Figure 5). Hedgerows trap sediments at their base thereby minimizing soil erosion and surface runoff velocity while check dam is a structural form of soil and water conservation measure (Figure 6), which is appropriate for areas with gully erosion. Cuttings of kakawate (Gliricidia sepium) were planted along the contours to serve as a soil and water conservation measure, and restore soil fertility. Kakawate is also a leguminous tree that has the potential for soil amelioration. Meanwhile, Yuan et al. (2019) reported that sediment discharge is being reduced by $83.92 \%$ in the watershed as influence by the check dam system.

The establishment of the tiger grass-based agroforestry model in the study site was an initiative of a multi-agency technical working group composed of the state universities and government sectors. The technical working group works towards institutionalizing the multi-agency implementation and promotion of agroforestry technologies; replicate the tiger grass-based agroforestry model in other upland communities within the CALSANAG watershed; explore for other alternative livelihood activities of the tiger grass farmers; and, conduct continuous education and awareness programs among the upland farming communities towards sustainable natural resources management of the watershed. Lessons from many development projects indicate the value of multisectoral collaboration in natural resources management (Prager 2010; Hvenegarrd et al. 2015); community-based development projects (Landicho et al. 2009; Cruz et al. 2011; Elauria et al. 2017) and agricultural innovations systems (Eidt et al. 2020).

In summary, research results suggest that there are economic and environmental challenges confronting the current tiger grass production of farmers in CALSANAG 
Watershed. This farming system does not satisfy the economic requirements of the farmers, while contributes to environmental degradation. The upland farmers recognized the need to integrate other crop species in their farms, and employ farming practices that would help restore and improve their degraded environment. This research also suggests the need for the establishment of a tiger grassbased agroforestry model to showcase the viability of crop diversity to address socioeconomic concerns of the upland farmers, and integration of woody perennials and soil and water conservation measures to address the need for ecological restoration of the watershed. As designed, the tiger grass-based agroforestry model aims at addressing a balance between the socioeconomic and ecological concerns of the entire farming household and in the long run, for sustainable natural resource management of the CALSANAG Watershed.

\section{ACKNOWLEDGEMENTS}

The authors acknowledge the Department of Science and Technology, MIMAROPA through the Provincial Science and Technology Center, Romblon for funding the research, and the farmers in Barangay Mari-norte, San Andres, Romblon who served as research participants.

\section{REFERENCES}

Alam MJ, Ali MR, Sarmin NS, Miah MMU, Shahjahan M. 2013. Existing marketing system and economic analysis of Broom grass (Thysanolaena maxima Roxb: Poaceae). J Agrofor Environ 7 (1): 81 84.

Andres A. 2013. Overview of the Philippine Biodiversity Strategy and Action Plan Formulation Process. Presentation at the National Consultation for the Updating of the PBSAP, Pasig City, Philippines, November 2013; in Department of Environment and Natural Resources-Biodiversity Management Bureau. 2014. The Fifth National Report to the Convention on Biological Diversity, Manila, Philippines.

Antonio E, Bass S, Gasgonia D. 2012. Philippines experience, lessons, and challenges in environmental mainstreaming. IIED, UK.

Armas K, Moralde R. 2019. An In-Depth Study of the Production Practices of Broom Reed Industry of the Philippines. Intl J Adv Eng Manag Sci 5 (1): 63-72. DOI: 10.2139/ssrn.3463599.

Badayos, R.B, R.A Coma, W.C Cosico, J.D Labios, I.J Manguiat, S.M Medina, P.M Rocamora and P.B Sanchez. 2007. Soil Science Laboratory Manual, Agricultural Systems Cluster, CA-UPLB, Philippines.

Baldino TS. 2002. Growing tiger grass under Benguet pine stand. Canopy Intl 28 (1): 2

Banjade M, Paudel N. 2008. Economic potential of non-timber forest products in Nepal: myth or reality?. J For Livelihood 7 (1): 36-48.

Beliveau A, Davidson R, Lucotte M, Lopes LOC, Paquet S, Vasseur C. 2015. Early effects of slash-and-burn cultivation on soi physicochemical properties of small-scale farms in the Tapajós region, Brazilian Amazon. J Agric Sci 2015,153, 205-221. DOI: 10.1017/S0021859613000968

Belcher B, Perez MR, Achdiawan R. 2005. Global patterns and trends in the use and management of commercial NTFPs: Implications for livelihoods and conservation. World Dev 33 (9): 1435-1452.

Bora I. 2014. Economic analysis of broom grass intercropping with pigeon pea (arhar) in Karbi Anglong. Manjari 1 (1): 6-7.

Bruun, TB., AD Neergaard, D. Lawrence, AD Ziegler. 2009. Environmental consequences of the demise in swidden cultivation in Southeast Asia: Carbon storage and soil quality. Hum Ecol (2009) 37:375-388 DOI 10.1007/s10745-009-9257-y
Catacutan DC. 2001. Technical Innovations and Institution-Building for Sustainable Upland Development: Landcare in the Philippines. Paper presented to The International Conference on Sustaining Upland Development in Southeast Asia: Issues, Tools and Institutions for Local Natural Resource Management ACCEED, Makati City, Philippines May 27-30, 2001.

Chechina M, Neveux Y, Parkins JR, Hamann A. 2018. Balancing Conservation and Livelihoods: A Study of Forest-Dependent Communities in the Philippines. Conserv Soc 16: 420-30.

Coronel RE. 1996. Pili nut. Canarium ovatum Engl. International Plant Genetic Resources Institute, Rome.

Cruz RVO, Tapia MA. 2005. A Review of the Multi-Sectoral Forest Protection Committees in the Philippines. ODI Forestry Briefing, Number 6. Overseas Development Institute, London.

Department of Environment and Natural Resources-Biodiversity Management Bureau. 2014. The Fifth National Report to the Convention on Biological Diversity. Department of Environment and Natural Resources-Biodiversity Management Bureau, Manila.

Eidt CM, Pant LP, Hickey GM. 2020. Platform, participation, and power: how dominant and minority stakeholders shape agricultural innovation. Sustainability 12 (2): 461. DOI: 10.3390/su12020461.

Elauria MM, Manilay AA, Abrigo GNA, Medina SM, Delos RRB. 2017. Socioeconomic and environmental impacts of the conservation farming village project in upland communities of La Libertad, Negros Oriental, Philippines. J ISSAAS 23 (2): 45-56

Fadriquel OG. 2016. Design and development of tiger grass pollen remover con wood working machine. Intl J Res Eng Technol 5 (5): 379-386.

Fernando ES, Balatibat JB, Perlas JR, Jumawid, RIJ. 1998. Resource inventory and assessment of biodiversity in Subic Bay Metropolitan Authority, Philippines.

Hauser S, Lindsey N. 2013. Slash-and-burn agriculture, effects of. In: Levin SA. (ed.). Encyclopedia of Biodiversity, 2nd ed, Vol. 6, Academic Press, Waltham, MA.

Hvenegaard GT, Carr S, Clark K, Dunn P, Olexson T. 2015. Promoting Sustainable Forest Management Among Stakeholders in the Prince Albert Model Forest, Canada. Conserv Soc 2015-13: 51-61.

Khan CA, Pervaiz U, Khan NM, Ahmad S, Nigar S. 2009. Effectiveness of demonstration plots as extension method adopted by AKRSP for agricultural technology dissemination in District Chitral. Sarhad J Agric 25 (2): 313-319.

Khoury K, Castaneda-Alvarez NP, Achihanoy HA, Sosa CC, Mulualem VB, Kassa T, Norton SL, Van der Maesen JG, Upadhyaya HD, Villegas JR, Jarvis A, Struik PC. 2015. Crop wild relatives of pigeon pea [Cajanus cajan (L.) Millsp.]: Distributions, ex situ conservation status, and potential genetic resources for abiotic stress tolerance. Biol Conserv 184: 259-270. DOI: 10.1016/j.biocon.2015.01.032

Landicho LD, Cabahug RD, de Luna CC. 2009. Engaging school-led multisectoral collaboration: implications to agroforestry promotion in the Philippines uplands. J Agric Educat Ext 15 (1): 69-79.

Landicho LD. 2016. Climate change adaptation strategies of smallholder agroforestry farmers in the Philippines. J Environ Sci Manag 19 (1): $37-45$.

Landicho LD, Visco RG, Paelmo RF, Cabahug RD, Baliton RS, Espaldon MO, Lasco RD. 2015. Field-level evidence of climate change and adaptation strategies of smallholder farmers in Molawin-Dampalit Sub-Watershed, Makiling Forest Reserve. Asian J Agric Dev 12 (2): 81-94.

Landicho LD, Dizon JT, Rola AC, Baconguis RDT, Quimbo MAT. 2017. Can agroforestry farmers attain sustainability? Case of farmers in selected upland farming communities in the Philippines. Intl J Agric Syst 5 (2): 101-119.

Leakey RRB. 2017. Definition of agroforestry revisited. In: Multifunctional Agriculture - Achieving Sustainable Development in Africa, RRB Leakey, 5-6, Academic Press, San Diego, California, USA.

Liu J, Moe KT. 2016 Economic contributions of non-timber forest products (NTFPs) to rural livelihoods in the Tharawady District of Myanmar. Int J Sci 5: 10-21. DOI: 10.18483/ijSci.904.

Lucidos JG, Formalleza AA, Andalecio EV, Mannoy R, Gan H, Rodeo AM. 2017. Avifaunal inventory in the different ecosystems of CALSANAG Balgo Sub-Watershed, Calatrava, Romblon.

Magurran AE. 2004. Measuring Biological Diversity. Blackwell Publishing, Carleton, AU.

Neto ECS, Pereira MG, Frade EF Jr., SB da Silva, de Carvalho JA Jr., JC dos Santos. 2019. Temporal evaluation of soil chemical attributes 
after slash-and-burn agriculture in the Western Brazilian Amazon. Acta Sci Agron 41: e42609, 2019. DOI: 10.4025/actasciagron.v41i1.42609

Prager K. 2010. Local and regional partnerships in natural resource management: The challenge of bridging institutional levels. Environ Manag 46: 711-724. DOI 10.1007/s00267-010-9560-9.

Pollini J. 2014. Slash-and-burn agriculture. In: Thompson PB, Kaplan DM (eds.) Encyclopedia of Food and Agricultural Ethics, Springer, Berlin. DOI: 10.1007/978-94-007-0929-4_87.

Ros-Tonen MAF, Wiersum KF. 2005. The scope of improving rural livelihoods through non-timber forest products. People Trees Livelihoods 15 (2): 129-148.

Sespene JS, Fetalvero EG, Faminial TT. 2011.Tiger grass industry in Marigondon Norte, San Andres, Romblon: Implications for Research and Development. Travesia 1 (1): 82-96.
Sarkar S, Panda S, Yada KK, Kandasamy P. 2018. Pigeon pea (Cajanus cajan) an important food legume in Indian scenario-A review. Legume Res LR-4021; 1-10.

Tiwari BK, Shukla RP, Lynser MB, Tynsong H. 2012. Growth pattern, production, and marketing of Thysanolaena maxima (Roxb.) Kuntze: An important non-timber forest product of Meghalaya, India. For $\begin{array}{lllll}\text { Trees Livelihoods } 21 & \text { (3): 176-187. }\end{array}$ 10.1080/14728028.2012.732793

Tolentino LL, Landicho LD, de Luna CC, Cabahug RD. 2010. Case Study: Agroforestry in the Philippines. In: Tracy CL (ed.). Handbook on Climate Change and Society. Routledge, New York.

Yuan S, Li Z, Li P, Xu G, Gao H, Xiao L, Wang F, Wang T. 2019. Influence of check dams on flood and erosion dynamic processes of a small watershed in the loss plateau. Water 11: 834 . 